\title{
Shame and its Histories in the Twentieth Century ${ }^{1}$
}

\section{BARBARA BROOKES}

Human emotions have been described as 'a map of our values'. ${ }^{2}$ In this paper I want to argue for a new direction in our history that takes emotions seriously. What role did hope play, for example, in propelling immigrants to this side of the world? What was the emotional content of the conversion experience that led some Maori to adopt Christianity? How do we understand desire as a motivating force for people's actions in the past?

How, I want to ask, might we understand the history of twentieth-century New Zealand if we explore the shifting and gendered terrain of shame, and thus attempt to get at what Raymond Williams describes as, 'The most difficult thing to get hold of, in studying a past period, is this felt sense of the quality of life at a particular place and time: a sense of the ways in which the particular activities combined into a way of thinking and living'. ${ }^{3}$

Values are something that historians have often charted in a whiggish and triumphalist mode: from out of the darkness of 'puritanism' and prejudice into the light of reason. ${ }^{4}$ To do otherwise implies an unwarranted nostalgia for the world we have lost. The fact that we no longer shame the failed breadwinner, or the woman sexually active outside of marriage - two of the themes I want to explore - is taken to be a triumph of modernity and secularization. James Belich in Paradise Reforged charts a move from, in his words, a 'tight society' to a great loosening. ${ }^{5}$ Yet in framing the history of shame that way, we may 'lose a crucial opportunity to reflect on what makes our society different or the same'. ${ }^{6}$ Tracing those shifts, I suggest, illustrates how people once lived in very different emotional communities, in which shame provided the glue that bound together individual desires and family responsibilities.

Shame, Bernard Williams argued, works for us in essential ways: 'By giving through the emotions a sense of who one is and of what one hopes to be, it mediates between act, character, and consequence, and also between ethical demands and the rest of life'. ${ }^{8}$ Elspeth Probyn connects shame to interest, noting that it 'constitutes lines of connection between people and ideas. It describes a kind of affective investment we have in others'. When that investment is questioned or interrupted, she suggests, 'we feel shame'. An historical exploration of shame might, therefore, help us comprehend both the feelings of women and men and also their relationship to the wider 
gendered terrain of social life. ${ }^{10}$ It may help answer Lucien Febvre's 1942 call 'to reconstitute the emotional life of the past'. ${ }^{11}$

There is current talk of 'the emotional turn' in history, following the 'linguistic turn'. Initially led by the work of Peter Stearns on America, the focus on emotions has been taken in a different direction through engagement with the psychological literature by William Reddy examining 'emotional regimes' in revolutionary France. ${ }^{12}$ Medievalist Barbara Rosenwein, has explored the idea of 'emotional communities'. ${ }^{13}$ While the linguistic turn emphasized the role of language in shaping the past, the emotional turn asks us to move beyond words into feelings. Often, it must be said, historians are limited to words - but at times, ritual and gesture suggest feelings. Other historians have focused productively on one emotion - Joanna Bourke, for example, on fear. ${ }^{14}$ I suggest that an examination of some instances of shame, an emotion central to human development, can lead to new and productive insights about our national history.

To work on feelings is a challenging task for historians who usually rely on formal sources where emotions rarely surface. Historians of religion have paid surprisingly little attention to emotion in the places where it might be expected to spill over, in the confession box, in the church pew and the minister's office. Recognizing the emotional content of belief, perhaps, undermines their enterprise of rational history. Private letters offer particular scope for the exploration of emotions, such as those reprinted in Sophie Jerram's Posted Love. ${ }^{15}$ Deborah Montgomerie's study, Love in the Time of War, lays the wartime 'emotional minefield' open to inspection. Here, she argues, the texture of wartime life 'was woven out of private worry, not public heroism. ${ }^{16}$ Shame is an even more difficult quarry for the historian than love, since we glory in love but revile shame. Individuals don't like admitting their shame to themselves, never mind making it public.

The one substantive New Zealand study to address shame is Joan Metge's In and Out of Touch: Whakamaa in Cross Cultural Context. Shame is only one of the meanings of Whakamaa which Metge describes as 'a word standing for a concept which Maori use in the process of organizing and talking about their experience of being human'. Metge argues that the combination of concepts that Whakamaa covers - shyness, inadequacy, embarrassment, fear, depression - are united by 'the lack or loss of mana in relation to others'. Whakamaa originally meant 'making oneself white', white being the unmarked opposite of red, the colour of high rank and value. ${ }^{17}$ It is ironic that in the twentieth century a symbolic inversion occurred as 'whiteness' took on status. As Mihi Edward's autobiography records, a 'false' white life of being a Pakeha was preferable for some Maori because of the shame they were made to feel 'of being born with brown skin'. ${ }^{18}$ 
Actions that were shameful in Maori society might become irrelevant in the face of cultural dislocation. ${ }^{19}$ Noa and tapu were undermined, for example, by the very design of Pakeha houses where eating and sleeping took place under one roof. The potential for not understanding Pakeha ways heightened opportunities for shame. Makere Harawira, born in Christchurch in 1945, recalled that although raised as Pakeha, she had an 'inner sense' of being Maori, and a sense that if 'indeed we were Maori it was because someone, somewhere had done something wrong'. ${ }^{20}$

By the 1960s a growing Maori population and increased assertiveness led to resistance to the social stereotyping of Maori that, in the words of philosopher David Velleman, left 'no room for self-presentation'. ${ }^{21}$ In 1964 the Maori Women's Welfare League succeeded in having a Department of Education publication, Washday at the $P a$, withdrawn because, they argued, it misrepresented Maori, their living conditions and their culture. ${ }^{22}$ By this time, the tables were beginning to turn and people were reassessing where the burden of shame lay. Whereas once Maori were made to feel ashamed of their language and culture, by the 1960s, the leaders of Maoridom were increasingly determined to shame Pakeha for their lack of cultural understanding. The Maori Women's Welfare League could shame Pakeha for their ignorance of Maori language (misuse of the word 'pa') and knowledge of Maori custom (not understanding the concepts of noa and tapu). The Maori Council Newsletter stated in 1963: 'We would like all pakehas to know they would always be welcome at Maori gatherings, though naturally we would hope that they would understand the correct way of behaving on the marae and in the meeting house'. ${ }^{23}$ Pakeha ignorance of tikanga Maori increasingly became a source of shame. It is this kind of turning of the tables on shame that interests me here.

Before I turn to the particular shifts in cultural values which are the main focus in this essay, breadwinning and illegitimacy, I will briefly discuss three levels of shame - the national, the familial and the individual - to indicate how individual and collective feeling might have an interpretative force in our national history.

National shame is a topic that might well interest those concerned with establishing a nationalist narrative for New Zealand history. Shame has been at the forefront of the History Wars in Australia since the 1992 Mabo judgement when Mr Justice Deane said that the colonization of Australia was, 'a conflagration of oppression and conflict which was, over the following century, to spread across the continent to dispossess, degrade and devastate the Aboriginal peoples and leave a national legacy of unutterable shame'. ${ }^{24}$ The character of the Australian nation is at stake in the History Wars. 
In New Zealand, the role of the Crown in the Treaty of Waitangi has, in a sense, removed responsibility from the nation. It is the Crown - something seen to be outside of the country - rather than the nation, which offers an apology to Maori in the settlement of claims.

The 2006 documentary Try Revolution reminded New Zealanders of the way the campaign against sporting contacts with South Africa tried to shame the government into taking a stand in 1981. The most divisive issue New Zealand faced in the late twentieth century was framed in terms of shame. The rugby match planned with the Springboks at Gisborne was seen not as 'a game' but as 'a day of shame' as posters from the Stop the Tour Action Committee record. This was part of the anti-tour effort to remind the nation of a commitment to the Gleneagles agreement, under which the government was to discourage sporting contacts with South Africa. ${ }^{25}$ Photographs of the 'day of shame' indicate the centrality of shame to national politics. Individuals who felt a deep investment in combating racism, who took pride in New Zealand as a just society - and believed the nationalist narrative of an egalitarian society - were deeply ashamed that the government failed to live up to the spirit of the Gleneagles agreement.

Familial shame works in different ways. Skeletons in the closet can shape family histories: a family story of rape and infanticide was only told to me by my mother after my father's death; shame had kept that door locked throughout his life but it explained so much about his over protectiveness towards his daughters. Shame can lead to people being written out of the family tree, as in one story told to me of a granddaughter expunged from the record as late as the 1990s, because she was born outside of marriage in 1983.

Shame can also determine people's futures. In 1954, nine-year-old David Lange recognized 'that some matter of considerable upset had taken place' within his parents' world. His father, a general practitioner, was accused of inappropriate behaviour during the gynaecological examination of a woman patient. The police laid charges, there was a depositions hearing, a grand jury, and finally a trial in the Supreme Court. 'Somehow or other', David Lange records, 'Pop kept going'. Just before the trial began, young David was informed by a family friend that he 'was going to have to be the man of the house' and, for the first time, he realized that his father might not come home. He 'could not bear to watch' the trial. Acquitted, Dr Lange 'never again saw a woman patient without a Nurse being present, and he never again allowed the police to call on his services'. The effect on young David, he recalled, 'was immediate. There was only one thing for me to do: I was going to be a lawyer'. ${ }^{26}$ And the rest, we might say, is history. 
Finding no positive way of self-presentation might be at the heart of an individual's feelings of shame. Here's John, from the 1990 book Will the Real Mr New Zealand Please Stand Up?

The only encounter I had with the whole business of being gay, was that I happened to go into a public toilet and a guy pulled me against the wall and that of course had the effect of making me feel worse about myself. Because if gay people were people who went and waited by lavatory walls and that was all they ever did, then I must be a pretty sort of sick individual. So, I grew up with very much that sort of feeling and as a consequence tried to stop it. ${ }^{27}$

John's story reminds us how gay pride was asserted precisely to counter such individual feelings of shame. ${ }^{28}$ The accusation of seeking a homosexual encounter was enough to bring down Colin Moyle in 1977. The history of homosexual law reform, culminating in the 1986 Homosexual Law Reform Act, marks a major transition away from the association of homosexuality with shame. Bill Logan, born in 1948, described the importance of this transition.

When homosexuality is a secret, it is a secret because it is felt to be shameful. So it is not surprising that I was immensely helped in the process of coming to accept myself by other people's openness about their homosexuality. It is not conducive to psychological health to be ashamed of central aspects of one's personality. But extinguishing the shame requires breaking the secret. I have found that being open to myself has required me to be open to my family, my friends and to the world. ${ }^{29}$

What was once an individual emotion helped create a movement that led to national political change: gay shame was converted to gay pride. Gay pride as a political movement was 'premised on the eradication of shame'. ${ }^{30}$ When discrimination of the basis on sexual orientation became unacceptable through the 1993 Human Rights Act, this helped move the burden of shame on to those who regarded homosexuals as, in some way, lesser beings.

Shame can act destructively - to patrol the borders of normality - and in a constructive way - to manage antisocial behaviour. Hence, we can imagine, the things regarded as shameful change over time. ${ }^{31}$ Male willingness to embark on military service provides one salient example. In 1915 and 1916, so-called 'shirkers' were publicly vilified when national honour required that men enlist to fight. Men who refused to volunteer (and hence face the high risk of death or maiming) were labeled as 'cowardly undesirable specimens of manhood'. ${ }^{32}$ Some women reinforced a conception of martial manhood by sending unenlisted men white feathers. ${ }^{33}$ In the twenty-first century, those men who endured great shame and resisted all measures to make them fight, 
such as Archibald Baxter, have become national heroes. ${ }^{34}$ One conception of appropriate masculine values, centred on patriotism towards Empire, has now been replaced by another, skeptical of imperial and martial ends.

In what follows I want to explore how male responsibilities towards families were reinforced in everyday life through shame. Traditional shorthand explanations that 'patriarchy' determined family roles are unsatisfying - they seem to explain everything at once and nothing in particular. My interest is in the affective investment people had in others, particularly in families, and how, when that investment was questioned or interrupted, people felt shame. ${ }^{35}$ Keith Oatley describes emotions as 'social effects' which result from the discordance of individual behaviour with wider social goals. ${ }^{36}$ The history of emotion, and, in this case shame, promises to provide insights into the felt experience of the past and its social structures.

Families once had a collective reputation that they held to be of more account than each individual member's 'personal preference' and this convention was supported in the wider culture. ${ }^{37}$ An exploration of the 'emotional communities' of the past and their imperatives may lead us to new insights into family structures. Criminal cases, because they involved lengthy investigation and written depositions, provide an important entrée into the exploration of feeling.

The case of a Dunedin man unfolded in 1912 as a story of failed manhood: a father despised by his family for his failure to work. Sixty-two-year-old Robert Turner was the father of seven children. His wife claimed he had been given to excessive drinking for 30 years. A butcher by trade, he had worked very irregularly and from 1901 'he had neglected his family' all of whom had to work from 'an early age' and his wife had 'to go out washing'. Robert's estrangement from his family was such that he mainly lived in a stable on the property. 'Family broils' over Robert's indifference to work were frequent and his wife said that 'he often threatened on these occasions, ${ }^{38}$

On the morning of 31 August, a younger son heard more of 'the barneying' that went on between Robert and his elder son Percy about the father's failure to work. Twenty-five-year-old Percy, a traveller, 'remonstrat[ed] with his father because of his indolence' and became so annoyed he struck him and then turned his father out of the house. Percy said that if his father didn't look for work, he would leave. The father had kept a rifle loaded for seven months 'because he feared he would be attacked'. 'I was frightened of him' he said of Percy - 'it was because I would not work he got on me'. Mrs Turner tried hard to keep the peace in this household of seething emotions. On the day of the murder she gave her husband his lunch early, 'hoping to get him out of the way before the son returned' - 'she was afraid 
of quarrels' ${ }^{39}$ When Percy came for lunch he wanted to know 'where father was and whether he had gone to work or not'. When told that his father was in the stable, he went there with a revolver but his father shot him first. When tried for murder, Robert Turner was acquitted on the grounds of insanity, described as suffering from acute alcoholic paranoia. He ended his days confined in the Seacliff Mental Hospital.

The Turner household had been brought to crisis by the refusal of the father to act as a breadwinner. In the eyes of his son he shamed his family. The mother and children were forced to go out to work in order to support themselves and an idle man. Since his father would not, in his eldest son's eyes, act like a man, he no longer deserved to be part of the household. Robert Turner dealt with his failings through drink and, fatally for his son, by self defence.

To be a breadwinner was, as this desperate story reveals, to work for others: to support a wife and family. The framework of expectations regarding breadwinners, upheld by higher male wage rates and union awards, placed a heavy burden on men - but it was the expectations from within the family and the shame of public failure within the community that governed everyday life. Such expectations were brought to bear on young men who made women pregnant outside of marriage, who were often expected, both by their own families, and those of the woman, to complete the sexual contract through marriage. The number of first births within nine months of marriage points to the strength of social sanctions. ${ }^{40}$

A sense of failure as a man might lead, in extreme cases, to suicide. In a rare insight into an emotional state, we have the suicide note of a 'company promoter' who took his own life on the 4 September 1928. He wrote to his wife:

\section{Dear Emily}

I am done and will only be a burden on you if I live, and as you are, and always have been a perfect woman, I feel I cannot live up to your ideals, being a failure.

I herein enclose sufficient money to pay for my burial expenses, and I hope, leave you sufficient to carry on till you can realize on the furniture and get life insurance.

My estate is bankrupt without me, so see Mr A Duthie and hand over everything of mine to the bank. If there is a "Hereafter" I will get in touch with you.

Love to Muriel John \& Vera

He continued outlining his financial affairs and ended: 'You are a good woman but you are too exacting for me. You are never put under temptation like me'. ${ }^{41}$ 
Here the wife appears as the shamer and the husband as the shamed. Her goodness appeared as a constant reproach to him and he felt he could never measure up. For this man, there appeared to be only one escape from public and private shame.

The role of family breadwinner was so central to what it meant to be a man that for a wife to seek work outside the home brought shame. Working class women's attempts to keep the family fed through taking in sewing or washing, or even working in someone else's home, kept private the shame of the breadwinner's failure. Women were complicit in upholding the status of the breadwinner.

In a remarkable insight into the salience of gesture, we can get a hint of a wider cultural practice. Sarah, interviewed in the 1970s, said she went to work only once after her marriage in the 1920s. She worked for about five weeks taking someone's place helping to serve in a shop. All the time she was serving in the shop her husband refused to work and he donned her pinafore: that quintessential item of clothing invariably worn by women engaged in household tasks. Sarah's mother warned her 'the sooner you put the pinafore back on the better'. Sarah said: 'I didn't go after that - he said that women didn't go to work where he came from, that was his attitude. He said, 'If I can't keep you, then there is something wrong'. She added wistfully: 'It was the loveliest five weeks I ever had, I really enjoyed it'. ${ }^{42}$ Sarah's mother was shamed by her son-in-law's decision to abandon work and wear the pinafore. His actions shamed his mother-in-law and were intended to shame his wife. He won in the battle of wills.

There is a good deal of evidence that even when unemployed in the 1930s, men resisted the shame of having a working wife. Marion Cooper (b.1925) recalled that, although her father was often out of work - 'it was depression time' - he refused to countenance his wife's return to work, even though the grandmother of the family was willing to take over managing the house. '[D]ad went mad and said if you are going to work then I am staying at home'. ${ }^{43}$

The shame of a working wife was temporarily overcome by wartime needs for labour from 1939 but the Second World War, while opening up new employment opportunities for a select number of women, 'did little to challenge the gender order that insisted a woman's most important sphere of activity was her home'. ${ }^{44}$ Sir Paul Reeves said of his mother taking a factory job making handkerchiefs in 1946 that 'my father was very upset . . . but we needed the money'. ${ }^{45}$ Married women's work could be accommodated if it was - like the breadwinners - on behalf of others, usually for the children - and once they were at school.

In the 1950s, the demand for women's labour in the workforce fostered a change in attitudes towards women working once their children were 
at school, but many men and women still held to the ideal of the male breadwinner. Fears of family breakdown were expressed through the phrase 'latch key children': those unfortunates who came home to an empty house because their mothers were at work.

The 1960s and 1970s saw married women increasingly leaving the home in search of paid employment. The rising number of married women in the workforce did not immediately alter the expectation that women were financially dependent on their husbands. In 1971, the Post Primary Teachers Association took up the matter of lack of transfer expenses for married female employees unless their husbands could be shown to be completely dependent on them (a proviso that did not exist for married men). The Department of Education responded: 'In our society the husband is regarded as fulfilling the role of breadwinner of the household and married women themselves, as a group, regard their husband's positions as being more dominant than their own'. ${ }^{46}$

The term 'breadwinner' was still 'universally identified with males'. ${ }^{47}$ A woman interviewed about the introduction of private sector equal pay in 1972, said that she opposed equal pay for women because a man needed to have 'something left, even if is a little bit of money in his pay packet every week'. If he didn't have that, she claimed, a man would be robbed 'of his ego' ${ }^{48}$ In her estimation, male pride relied on the breadwinner status. To reduce that status would result in shame.

But the tables were turning. Second wave feminism regarded the home as a prison from which women required liberation and demanded equal pay. Women confined to the home were diagnosed as suffering from suburban neurosis. Women at home found they increasingly had to explain themselves: it was hard not be ashamed of being 'just a housewife'. Bronwyn (1983) said defensively, 'I have to lay out all my reasons for staying home and being with the children. Sometimes I get very miserable about it . . . Everyone I meet says "where are you working now?" Because they know I've finished studying. ${ }^{49}$

There were still men who felt demeaned by their wives working but, on the whole, breadwinning for families became a joint endeavour, a change recognized and encouraged by the Labour governments of the first decade of the twenty-first century. Women have gained jobs and independence, and wages are no longer paid to breadwinners but to individuals. In Celia Lashlie's recent 'Good Man Project', which asked male teachers and young men what makes a 'good man' in the twenty-first century, the list of characteristics says nothing about 'breadwinning, ${ }^{50}$ We no longer have a strong concept of a wage tied to a family. What this sea change in values means is a question that requires further exploration. There is some British evidence that suggests a correlation between male joblessness and single 
motherhood. ${ }^{51}$ One New Zealand study of changes in paid work for midlife couples suggests that between 1981 and 2006, more women and fewer men were in paid work and that fewer such men and women were living as couples. ${ }^{52}$

The second twentieth-century transition I wish to explore very briefly concerns femininity and the importance of chastity and the shame of illegitimacy. For a good part of the twentieth century, sex outside of 'wedlock' was deeply shameful, for women in particular. The shame of pregnancy for an unmarried woman led to a variety of social consequences, such as being sent away from home for the duration of the pregnancy, having children adopted out, or an illegal abortion..$^{53} \mathrm{~A}$ historically-specific language marked that shame - 'an illegitimate child', 'an unmarried mother' - that changing attitudes have now rendered meaningless.

The intense shame attached to sexual behaviour outside of marriage has almost undergone a complete reversal. Here is actor Davina Whitehouse in the 1980s speaking of the 1940s:

I wasn't a bit interested in getting married, and didn't until I was twentyeight. I used to have lots of boyfriends. Mind you, sex wasn't 'in' then. We didn't have the pill so one didn't live with boyfriends, one was a virgin. I say with amazement that I went to the altar age twenty-eight a virgin. I've been ashamed of that for many many years, but now I think it's rather quaint. Sex has become so overt and general now. For us it was the terror of having a baby. And no way would or could I have lived out of marriage with a man. I would have had to cut myself off from my family to do that. ${ }^{54}$

In the period Whitehouse refers to, and earlier, families had an investment in seeing their daughters well-provided for within marriage before they had children. Marriage was an essential prerequisite for sexual intercourse because it created the framework for providing for children, through, as we have noted, the breadwinner's wage. A daughter who risked severing the line of interest between parents and children by engaging in sexual intercourse outside of marriage, invited individual and familial shame - a shame denoted by the community through the word "illegitimate", a child born outside of wedlock. Young women bore this shame in their bodies, and rarely articulated it. They tried to hide it from their families and their communities, and took desperate measures to deal with the shameful evidence of their sexual 'misconduct'. 55

Cases of women shamed through seduction and abandonment were occasions for public outcry. Truth launched a campaign in 1915 to fight for the release of Alice Parkinson. Parkinson, a domestic worker, had borne Albert West a stillborn child after a difficult labour. West had promised to 
marry Parkinson and she had put all her savings into buying furnishings for their home. Alice wrote to Bert: 'Did you go to the registry and fix things up? You might have called in to let me know if you did . . . Now dear I hope you prove yourself a man and keep your promise. ${ }^{56}$

When West repeatedly failed to fulfil his promise of marriage, Parkinson shot him. Despite the jury's recommendation that she be found guilty of manslaughter and dealt with mercifully, the judge, Robert Stout, found her guilty of murder and sentenced her for the term of her natural life. The harsh sentence led women's groups to call for Parkinson's release. The Women's Christian Temperance Union asserted that Parkinson had 'already been punished by the laws of nature'. Harry Holland, editor of the Maoriland Worker, made an impassioned speech in Alice's defence, saying 'It is always the woman who pays - who bears the full weight of the burden of shame and suffering . ..$^{57}$ In response to a petition signed by nearly seventy thousand people, Stout defended his verdict stating that there was no law that allowed a woman to assassinate a man who had seduced her.

Alice Parkinson's cause served to unite women across the political spectrum because she stood as a symbol of a woman 'ruined' by a man yet also as a woman who aspired to fulfill the feminine ideal of having a home and family. Her plight of being used and jilted was interpreted by many within the community as just provocation for murder since she had been robbed of the life to which she aspired. The debate over the Parkinson case was generally conducted in terms of male seduction corrupting an innocent woman. West's behaviour was portrayed as shameful and unmanly since he had apparently urged his friends to assault Parkinson and he had failed in his obligation to 'do right' by the woman he had made pregnant. The Parkinson case marked the height of public indignation at the plight of the woman who was 'a mother but no wife'. Women's groups were insistent that chastity outside marriage was the ideal for both sexes.

In the early twentieth century, Truth, ever sympathetic to the plight of working-class girls, gave readers moral tales and titillation through reporting court stories of abandoned young women, with its characteristic alliterative titles such as 'Duped, Deserted and in Distress'. ${ }^{58}$ In October 1919, the paper related the story of a 'girl-mother' aged 20. She had come to Wellington in January of that year and found a live-in job in a hotel. In the city 'a man ravished her but she didn't tell anyone about it'. She gave birth alone in a bathroom of the hotel, later stating that the child appeared to be alive. She took it back to her room and put it under her bed. A fellow employee saw the baby and advised her to get rid of it, so she threw the child down a gully. The evidence of a doctor that the child was likely born while the mother was in the bath and hence it drowned, relieved the young woman of the murder charge. ${ }^{59}$ 
In the reported cases, the shame of their situation led young women to hide their condition, to conceal births, and to commit infanticide. The shame alone seemed a just punishment for their crime and also their saving grace as magistrates, judges and juries found ways to excuse their crimes. ${ }^{60} \mathrm{In}$ the 1925 case of Maru, a young Maori girl who, the judge claimed, "never had a chance', the judge refused to accept a plea of guilty to the charge of murder of her illegitimate child. The judge commented that Maru had been, 'Seduced by a "worthless man" who deserted her in her time of trouble' and directed the jury to find a verdict of 'not guilty'. ${ }^{61}$ A 'shameless' woman, who had borne more than one illegitimate child and had no sense of remorse was unlikely to be received sympathetically.

Abortion was one solution for pregnancy outside of marriage and one sought by single women. In the course of the second of the four trials of a Hasting woman, Mrs Annie Aves, on the charge of procuring abortion in August 1936, the crown prosecutor stated: 'a mother, to save her daughter's name, might be condoned for a certain action, but not a person who sets up to perform abortions at lucrative fees' ${ }^{62}$ Annie Aves, however, escaped conviction although tried four times. Juries sympathized with the plight of young women trying to escape the consequences of sexual indiscretion.

A less dangerous solution to the problem of illegitimacy lay in leaving town, giving birth amongst strangers - called 'going up North' in Dunedin (but perhaps 'going down South in Auckland'?) - and having the baby adopted. Here is one of Anne Else's interviewees:

I remember my parents saying, 'We've made a name and a place for ourselves in this town and we're not going to have it spoilt by you, you'll have to go away.' But they wanted to do what was best for me too. They genuinely believed that if the baby was adopted out and I never saw it I would come back and start life again.

Eighty per cent of the women surveyed in one study of single mothers gave birth away from where they lived. ${ }^{63}$ Shame was contained by relocating and hiding the pregnancy from friends, family, and sometimes parents. Adoption provided a child with a 'respectable' family which included a breadwinning father. An unmarried woman's shame could be absolved by doing the 'best thing' for the child and releasing it from the stigma of illegitimacy.

The very best thing would be to prevent illegitimacy in the first place. The introduction of the contraceptive Pill into New Zealand in 1961 promised freedom from the risk of illegitimate children. Unmarried women at first found it difficult to get the Pill but it quickly helped sever the link between marriage and sexuality. Initially promoted as a means of creating happier families by allowing women to control of the age gap between children, the Pill increasingly came to be marketed as an indispensable item for all young women. ${ }^{64}$ As sexual activity by the unmarried became 
less stigmatized, young single women agitated to keep their children. The shift away from shame received government recognition in The Status of Children Act, 1970, which did away with the concept of the 'illegitimate' child. In 1973, the Labour government introduced a new statutory benefit: the Domestic Purposes Benefit for solo parents. In effect, the state stepped into the breadwinner role.

Chastity is no longer seen as a requirement to be a good Pakeha woman: in fact the tables have turned to the extent that admitting virginity might be an occasion for shame. But abortion rates are high amongst Pacific Island and Asian women where pregnancy outside of marriage is still associated with shame. ${ }^{65}$ In the early twenty-first century, Pakeha society privileges sexual expression and the market above other values, hence the aggressive advertising of the Pill to doctors and the legalization of sex work. What was once abnormal and shameful for women - sex outside of marriage - has become an ideological imperative proclaiming freedom from constraint and a valorization of youth (even the elderly are now enjoined to be sexually active). The shame of not being sexually desirable or active fuels the market for all sorts of commodities, Viagra perhaps being the one that most infects our emails.

Being a breadwinner is no longer a requirement of being a good man - whereas the Viagra advertisements suggest sexual performance perhaps is. One advertisement for the Pill (right) suggests that a woman would find it more reliable than any man. ${ }^{66}$

Tracing the individual shame of failed breadwinners or unwed mothers can connect, I suggest, to our national history. For a good deal of the twentieth century, many in New Zealand society shared a common goal of

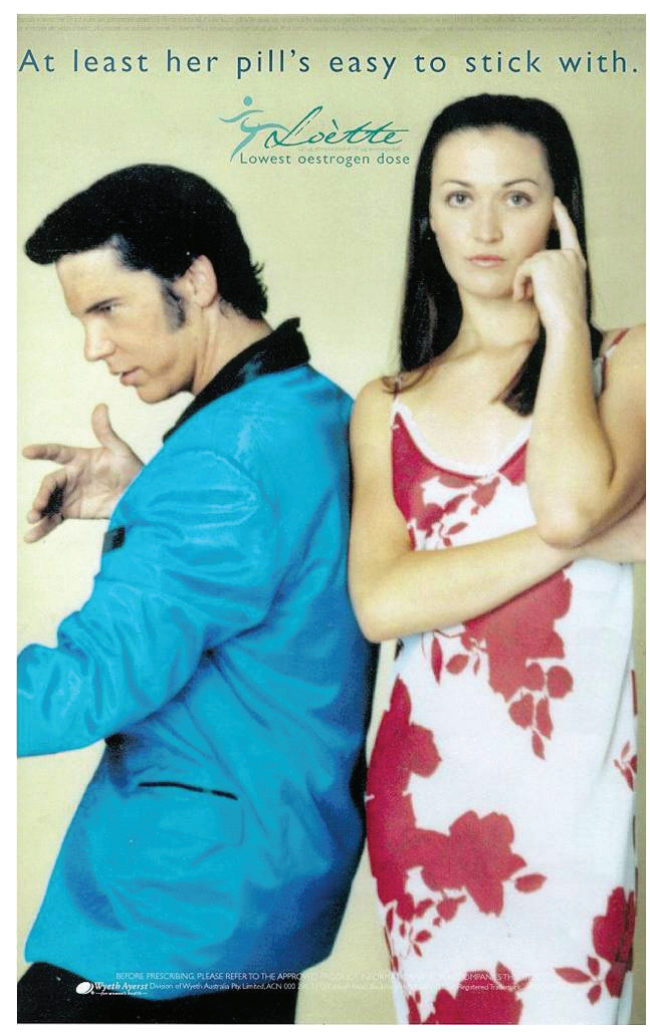

Loette advertisement, 2000. 
providing for children in a two-parent family setting with clearly demarcated gender roles. New Zealand prided itself on being a good place to bring up children, a reputation based on the capacity of male breadwinners to support families and women's commitment to putting family first. Shame helped keep in place certain lines of connection between parents and children. From the 1960s, society has become increasingly individualized and relationships became a matter of individual negotiation - rather than community sanctions. Smoking, an individual pursuit, has become more illicit than sex. Parents' work, and children's needs are fitted round the dictates of employers who see their employees as units, not part of families. Individuals work for individual wages and 'working for families' is something undertaken by government departments such as Work and Income, and Inland Revenue.

The early twentieth-century 'tight' society was predicated on a congruence between familial social expectations and the ideals of the state. The 'tight' society dictated conformity to codes of male breadwinning and female chastity - and those who offended suffered, sometimes grievously. But that society's shaming of people who neglected others may have benefited those with the least resources in terms of education and employment. No longer shaming those who fail to take responsibility for others may have unintended consequences for the most vulnerable. Here I'll speculate: perhaps a 'tight' society, for all its failings, did help reinforce a duty of care for children. Such a society might have pre-empted a 2007 incident of national shame and outrage in which the 34-year-old mother of a three-year-old was the sole income earner, working six days a week from early in the morning to late at night, in a household where a number of unemployed men, including her 17-year-old boyfriend, failed to take adequate responsibility for her child who died in their care. ${ }^{67}$ Those without hope for themselves may find it difficult to imagine the future lives of others. Perhaps the breakdown of the male breadwinning role and its obligations to family, described by Robert Griswold as 'the great unifying element in fathers' lives', has created a vacuum yet to be filled with new modes of responsibility towards children. ${ }^{68}$

My intention is not to suggest that that we turn back the clock, that we recreate the gendered domains and conformity of the 1950s. My point is that an understanding of past emotional communities allows us to see how people made meaning on their own terms, terms that are very different from ours. Just as their society had its imperfections, so does ours.

In her analysis of emotional communities, Barbara Rosenwein asks us to imagine,

a large circle within which there are smaller circles, none concentric but rather distributed unevenly within the given space. The large circle is the overarching emotional community, tied together by 
fundamental assumptions, values, goals, feeling rules, and accepted modes of expression. The smaller circles represent subordinate emotional communities, partaking in the larger one and revealing its possibilities and its limitations. ${ }^{6}$

My argument here is that tracing the history of shame can help us illuminate the changing outline of such circles and the relationships between them. Charting the shifting emotional terrain can assist us to re-examine how people understood their lives. In the mid-twentieth century, divorce was shameful and sex was not a word used in polite society. Personal standards of behaviour were reinforced through a wider social covenant that believed a two-parent family was the best setting for raising children. Since that time sexuality has been freed from the family setting and new family forms have come into existence. Individual preference might now, more acceptably, take priority over family expectations. The once proscribed, small circle of gay people, for example, has been validated and given greater visibility through law reform. The move to free homosexuality from associations with shame resulted in the 2004 Civil Union Act which gave same-sex couples equivalent rights and obligations to heterosexual couples. This is but one example of a significant, and rapid, historical transformation linked to reorienting the place of shame.

Shame is only one of a constellation of emotions that might be explored to understand our past. Emotions should be recognized as among the many forces capable of engendering historical change. ${ }^{70}$ They entail "judgments about whether something is good or bad for us' at the individual and at the wider social level. ${ }^{71}$ My purpose has been to outline some of the ways in which belief systems about what constitutes 'good' and 'bad' changed over the twentieth century. Such belief systems acted both to shape individual feelings and to determine wider state policies. As they change over time, the social meanings of emotions provide clues towards reading the past, understanding the affective life of individuals, and making sense of the porous membrane between the private and public world. This is what Darwin understood when he declared the blush to be 'the most peculiar and the most human of all expressions' ${ }^{72}$ In the emotional upheaval revealed by the flush of the skin lies a connection between the self and society.

1 The initial ideas in this paper were developed for a symposium given in August 2006 at a symposium at the University of Otago organized by Dr Wendy Parkins. Versions of the paper were presented as the Keith Sinclair Lecture at the University of Auckland in October 2006 and my Inaugural Professorial Lecture in July 2007. I wish to thank all the audiences for feedback and, in particular, my University of Otago colleagues Charlotte Paul, Annabel Cooper, Mark Seymour, Brian Moloughney, and John Stenhouse for their valuable input into helping me shape my ideas. 


\section{Journal of New Zealand Studies}

2 Keith Oatley, Emotions: A Brief History, Oxford, 2004, p.42. See also Martha C. Nussbaum, Upheavals of Thought: The Intelligence of Emotions, Cambridge, 2001.

3 Raymond Williams, The Long Revolution, Harmondsworth, 1965, p.63.

4 John Burnham does not take this progressive view of changing values but suggests that adoption of working class behaviours and outside economic forces have created change. He does not address the question of shame. John C. Burnham, Bad Habits; Drinking, Smoking, Sexual Misbehavior, and Swearing in American History, New York, 1993. I use the term 'puritanism' as a shorthand but am aware of the term's misuse and complexities. See Marilynne Robinson, 'Puritans and Prigs', in The Death of Adam: Essays on Modern Thought, New York, 1998, pp.150-73.

5 James Belich, Paradise Reforged: A History of the New Zealanders From the 1880s to the Year 2000, Auckland, 2001, p.463.

6 Elspeth Probyn, Blush: Faces of Shame, Minneapolis, 2005, p.xiv.

7 Anthropologists have paid attention to shame in a variety of contexts, for just one example, see John G. Peristiany, Honor and Shame: The Values of Mediterranean Society, London, 1965.

8 Bernard Williams, Shame and Necessity, Berkeley, 1993, p.102.

9 Probyn, p.13.

10 My thinking on shame has been influenced by philosopher J. David Velleman's chapter, 'The Genesis of Shame', in Self to Self: Selected Essays, Cambridge, 2006, pp.45-69.

11 Lucien Febvre, 'Sensibility and History: How to Reconstitute the Emotional Life of the Past', in Peter Burke, ed., A New Kind of History: From the Writings of Febvre, translated by K. Folca, London, 1993, p.12. Through literature, Adela Pinch has examined feelings in the eighteenth and early nineteenth century, in Strange Fits of Passion: Epistemologies of Emotion, Hume to Austen, Stanford, 1996.

12 Peter N. Stearns, American Cool: Constructing a Twentieth Century Emotional Style, New York, 1994; Carol Z. Stearns and Peter N. Stearns, Emotions and Social Change: Towards a New Psychohistory, New York, 1988. William M. Reddy, The Navigation of Feeling: a Framework for the History of Emotions, Cambridge, UK, 2001.

13 Barbara Rosenwein, Emotional Communities in the Early Middle Ages, London, 2006.

14 Joanna Bourke, Fear: A Cultural History, London, 2005; Carol Zisowitz Stearns and Peter N. Stearns, Anger: The Struggle for Emotional Control in America's History, Chicago, 1986.

15 Sophie Jerram, Posted Love, Auckland, 1999.

16 Deborah Montgomerie, Love in the Time of War: Letter Writing in the Second World War, Auckland, 2005, p.132.

17 Joan Metge, In and Out of Touch: Whakamaa in Cross-Cultural Context, Wellington, 1986.

18 Mihi Edwards, Mihipeka: Early Years, Auckland, 1990, pp.125, 164.

19 Jonathan Lear, Radical Hope: Ethics in the Face of Cultural Devastation, Cambridge, 2006.

20 Makere Harawira, 'Fair-skinned, Blue-eyed', in Witi Ihimaera, ed., Growing Up Maori, Auckland, 1998, p.203.

21 Velleman, p.62.

22 Barbara Brookes, "Nostalgia for "innocent homely pleasures": The 1964 New Zealand Controversy over Washday at the Pa', Gender and History, 9 (1997), pp.242-61. 


\section{Shame and its Histories in the Twentieth Century}

23 New Zealand Maori Council Newsletter, vol.1 no.1, September 1963. MS-Papers -1396100, Alexander Turnbull Library.

24 Keith Windschuttle, The Fabrication of Aboriginal History: Volume One, Van Diemen's Land 1803-47, Sydney, 2002, p.3.

25 Trevor Richards, Dancing on our Bones: New Zealand, South Africa, Rugby and Racism, Wellington, 1999, p.255.

26 David Lange, My Life, Auckland, 2005, pp.53-55.

27 Gwendoline Smith, Will the Real Mr New Zealand Please Stand Up?, Auckland, 1990, p. 150 .

28 See Laurie Guy, Worlds in Collision: The Gay Debate in New Zealand, 1960-1986, Wellington, 2002.

29 Bill Logan, 'Never Exactly One of the Lads', in Michael King, ed., One of the Boys: Changing Views of Masculinity in New Zealand, Auckland, 1998, p.208.

30 Probyn, p.2.

31 Alan Hunt has explored changing moral behaviour, but has not investigated the role of emotions in Governing Morals: A Social History of Moral Regulation, Cambridge, 1999.

32 'The Shirkers,' Grey River Argus, 12 July 1916, p.4.

33 See, for example, Ashburton Guardian, 22 February 1915, p.4.

34 Archibald Baxter, We Will Not Cease, London, 1939.

35 Probyn, p.13.

36 Oatley, p.89.

37 Standish Meachem, A Life Apart: The English Working Class 1890-1914, Cambridge, 1977, p.27; Marilynne Robinson's discussion of morality has informed my thinking here, see The Death of Adam, p.170.

38 Transcript, Dr Alexander, DAAC/D256, 11/11/1912, Dunedin Regional Archives, NA.

39 Criminal Trial file, Evidence of Robert Franklyn Turner, son of accused, p.2. DAAC/ D256, 11/11/1912, Dunedin Regional Office, National Archives. This case was first discussed by Jane Adams in "“Criminal Lunacy": A Case Study of Seacliff Lunatic Asylum, 1882-1912', in B. Brookes and Jane Thomson, eds, 'Unfortunate Folk': Essays on Mental Health Treatment 1863-1992, Dunedin, 2001, pp.77-79.

40 Sceats et al.

41 Coronial Inquest files, Department of Justice, Series 46, no. 1151 of 1928, Archives New Zealand (Wellington). I am grateful to John Weaver and Doug Munro for this reference.

42 Wellington Branch, Society for Research on Women in New Zealand (Inc), In Those Days: A Study of Older Women in Wellington, Wellington, 1982, p.52.

43 Annabel Cooper, Erik Olssen, Kirsten Thomlinson and Robin Law, 'The Landscape of Gender Politics: Place, People and Two Mobilisations', in B. Brookes, A. Cooper, R. Law, eds, Sites of Gender: Women, Men and Modernity in Southern Dunedin 1890-1939, Auckland, 2003, p.34.

44 Deborah Montgomerie, The Women's War: New Zealand Women 1939-1945, Auckland, 2001, p.171.

45 Paul Reeves, 'My Mother Fashioned Me', in Witi Ihimaera, ed., Growing Up Maori, Auckland, 1998, p.155.

46 Select Committee on Women's Rights Report, Appendices to the Journals of the House of Representatives (AJHR), June 1975, I-13, p.17.

47 Ibid. 


\section{Journal of New Zealand Studies}

48 Television New Zealand, Our Voice and Our Vision, Documentary aired 17 September 1985.

49 Rosemary Barrington and Alison Gray, The Smith Women: 100 New Zealand Women Talk about Their Lives, Wellington, 1981, p.145.

50 Celia Lashlie, It's About Boys: The Good Man Project, Nelson, 2004.

51 Camilla Cavendish, 'Useless, jobless men? The Social Blight of our Age', Times Online, 28 May 2010, http://www.timesonline.co.uk/tol/comment/columnists/camilla_cavendish /article7138520.ece, accessed 5 July 2010.

52 Paul Callister, Martin von Randow, David Rea and Gerard Cotterell, 'Changes in paid work for mid-life couples between 1981 and 2006: A research note', http://ips.ac.nz /publications/publications/show/282, accessed 5 July 2010.

53 Anne Else, A Question of Adoption: Closed Stranger Adoption in New Zealand, 19441974, Wellington, 1991.

54 Judith Fyfe, Matriarchs: A Generation of New Zealand Women Talk to Judith Fyfe, Auckland, 1990, p.73.

55 Barbara Brookes, 'Reproductive Rights', in Barbara Brookes, Charlotte Macdonald and Margaret Tennant, eds, Women in History, Wellington, 1986, pp.119-36.

56 Cited in Carol Markwell, 'The Case of Alice Parkinson: Its Social and Political Context', DipHum Research Essay, Massey University, 1993, p.10.

57 Maoriland Worker, 28 July 1915, cited in Markwell, p.12.

58 Truth, 16 October 1909, p.7.

59 Truth, 4 October 1919, p.5.

60 Case of Margaret Burke, Truth, 17 February 1912, p.5. Counsel said a man (not the father of the still-borne child she had concealed) was prepared to marry her if the court was lenient. Counsel said she had already undergone humiliating punishment.

61 Truth, 17 December 1925, p.8.

62 Truth, 12 August 1936, p.20.

63 Else, p.29.

64 Claire Gooder, 'A Blank Cheque for Permissiveness: the Introduction of the Contraceptive Pill to New Zealand', BA (Hons) dissertation, University of Otago, 1999; Danielle Moreau, " "Living with the pill": Oral Contraceptive Use in New Zealand, 1960-1975', MA thesis, University of Auckland, 1997.

65 http://www.abortion.gen.nz/information/statistics.html, accessed 26 October 2010. Converted into rates per 1000 women aged 20-39, in 2005 the European rate was approximately 29; Pacific Island rate 37 and Asian rate 46. See also Diana Dekker, 'Student troubles', Evening Post, 29 June 2002, p.24.

66 Loette advertisement, used in both the New Zealand and Australian market in 2000. Supplied courtesy of Pfizer Australia Pty Ltd.

67 Nia Glassie Case, Sunday-Star Times, 5 August 2007, pp.A10, A18; C1, C3.

68 Robert Griswold citing Robert Rutherdale, 'Fatherhood and the Social Construction of Memory: Breadwinning and the Male Parenting on a Job Frontier, 1945-1966', in Joy Parr and Mark Rosenfeld, eds, Gender and History in Canada, Toronto, 1996, p.360; Robert Griswold, Fatherhood in America: A History, 1993, New York p.2.

69 Rosenwein, p.24.

70 Ibid., p.31.

71 Ibid., p.191.

72 Charles Darwin, The Expression of the Emotions in Man and Animals, 3rd ed., Oxford, 1998 , p.310. 